\title{
改善されたゴムコンパウンドの 加工安定剤システム
}

\section{林田隆 博*}

\section{Improved Processing Stabilizer Systems for Rubber Compounding}

Takahiro HAYASHIDA (Dr.Gerrit Knobloch Chris Fagouri Dr. Mouhcine Kanouni Ciba Specialty Chemicals Inc Basel, Switzerland)

The rubber industry is frequently confronted with processing problems resulting in bad distribution of components, low quality or even unemployable rubber compounds.

Reasons can be oxidative damage of the rubber because of extended storage or insufficient rubber stabilization, as well as oxidative cross-linking during mixing due to severe processing conditions. Standard rubber antidegradants such as TMQ and PPDs have a limited contribution to processing stability.

Specially optimized rubber processing stabilizers can reduce the problems caused by oxidative reactions during compounding. With these specially formulated antidegradant systems, it is possible to make black, natural or coloured compounds with a reduced tendency of gel formation in a broader temperature range.

Additionally, these fully formulated antidegradant systems can be employed in silica filled rubber compounds, e.g., tire treads, while, again broadening the processing window, reducing premature cross-linking, and reducing compound viscosity and hence compound temperature during mixing.

This article will cover new technology for improved processing and storage stability of rubber compounds, and offer information on recent advances in products that will allow for reduced scorching and higher temperature processing.

Key Words : Antidegradant, Processing Stabilizer, Silica Filled Rubber, Tire Tread, Scorching

\section{1.は じめ に}

チバ・スペシャルティ・ケミカルズは, プラスチック及 びエラストマー分野を中心とした自動車, 緎維製品, 包装 材や家庭用品などあらゆる製品の性能, 保護, 彩色, 強度 向上させるため活動をしている. 広い範囲でポリマーの安 定剤を供給しているが, その中でも加工安定剤, 長期熱安 定剂, 相乗剂, 金属不活性化剂, 蛍光増白剂, 耐候 (光) 安 定片が重要であり，さらに高機能性を付与する製品群であ る難燃剂，永久带電防止剂，抗菌剂や表面改質剤等の分野 において市場開拓および販売活動を促進する。

近年, 我々はゴム製品の高機能化について開発・研究を 進めている、ゴムの業界では, しばしばゴム配合組成の分 散不良, ゴムコンパウンドの使用不可に結びつくような品 質トラブルをおこす加工性の問題に直面している．ゴムの 練り条件で生ずる酸化による架橋と同様に, ゴムの長期保 管やゴムの不十分な安定性から，ゴムの酸化によるダメー ジが要因と考える．標準的なゴム熱劣化安定郕であるトリ メチルキノリンやパラフェニレンジアミンは, 加工安定性
の向上に限界がある.

我々の最優先である技術課題は，加工安定性を改善する ことである.ゴム製品の加工安定性や長期熱安定性は避け て通ることのできない問題であり，いずれも非污染性夕イ プを主軸とした製品群での検討を進める．特に最適化され た加工安定剤システムは，ゴムコンパウンド時の酸化反応 に起因する問題を減らすことができる，さらに黒物配合や 明色ゴムコンパウンドにかかわらず，より幅広い温度範囲 でゲル化量を低減すべきで，また再び加工性の幅を広げ， 架橋を抑制し，コらにゴムの練り工程時のゴムの温度や粘 度上昇を低下させ，シリカ配合ゴム(例えばタイヤトレッ ド)でも使用が可能である。 また，他の開発動向としては,

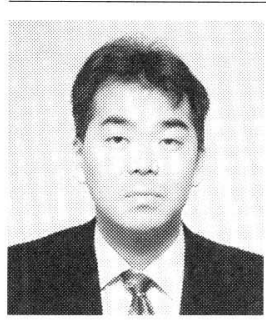

*チバ・スペシャルティ・ケミカルズ硛プラス チック添加剤セグメント (テ 105-6134 東京 都港区浜松町 2-4-1世界貿易センタービル 34 階). 昭和 60 年, 関西大学工学部応用化学科 卒業. 同年, 日本チバガイギー(株)入社, 現在 に至る。 
新規オゾン劣化防止剤の確立，ニトロソアミン化合物の抑 制剂, 遊離酸中和剂, 金属不活性化剂, 光安定剂, 紫外線 吸収剂等によるゴム製品の高機能化が今後の課題である.

ゴムをコンパウンドする場合，その架橋反応から加工性 に問題が生ずることはゴムの業界で知られており，さまざ まな原因が考察される。例えば，a）生ゴムの基本安定性 が不十分であり，b）生ゴムの長期保管あるいは過酷な輸 送条件下でのダメージがある，そして，c）厳しい条件下 でゴムをコンパウンドする．特に，生ゴムの倉庫保管時で のダメージはしばしば低く評価される，本文は，潜在的な 加工性の問題を定義づけその問題を避けるあるいは解決す る方法を検討した。

\section{2. 生ゴムの基本安定剤の長期安定性効果}

保管条件を想定するため，市販のポリブタジエンゴムの ベールを $60{ }^{\circ} \mathrm{C} て ゙ 24$ 週まで熱履歴を負荷するオーブン熱劣 化試験後の結果を要約する．高揮散性を示すBHT(ジブチ ルヒドロキシトルエン，以後安定剤 $\mathrm{A})$ ，低揮散性である Ciba ${ }^{\circledR}$ IRGANOX ${ }^{\circledR} 1076$ (オクタデシル-3- (3,5-ジ-tert-ブ チルー4ーヒドロキシフェニル)プロピオナート，以後安定 剂B) と多機能安定剂である Ciba ${ }^{\circledR}$ IRGANOX ${ }^{\circledR} 1520 \mathrm{~L}\left(4,6^{-}\right.$

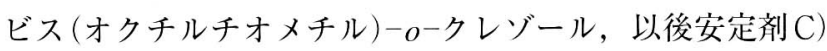
の 3 種類の酸化防止㓮を比較する．その安定剤の残量と残 った加工安定性の関係を考察するため，熱劣化時間との相 関関係を測定する．加工安定性はブラベンダー熱劣化試験 での誘導時間で評価し，すなわちトルクが1 $\mathrm{Nm}$ 上昇する までの練り時間を検討する.市販の生ゴムを評価したため, 安定剂の濃度は明らかに異なっている(すなわち $1.2 \% の$ 安定剂 A， $0.24 \%$ の安定剂 B及び $0.12 \%$ の安定剂 C). ᄂ たがって, 安定剤のロスや加工性の傾向を見極めるためゴ ムベールの表層と内部をそれぞれ試験する(図 1 ).

安定剤 $\mathrm{B}$ は，ゴムのベール表層と内部でほぼ一定した安 定剤濃度であるが,加工安定性は著しく低いレベルを示す。 一方，安定剤Cは，㧍よそ50\%減である安定剤量にもか かわらず，初期段階で高水準な加工安定性が見られる．予

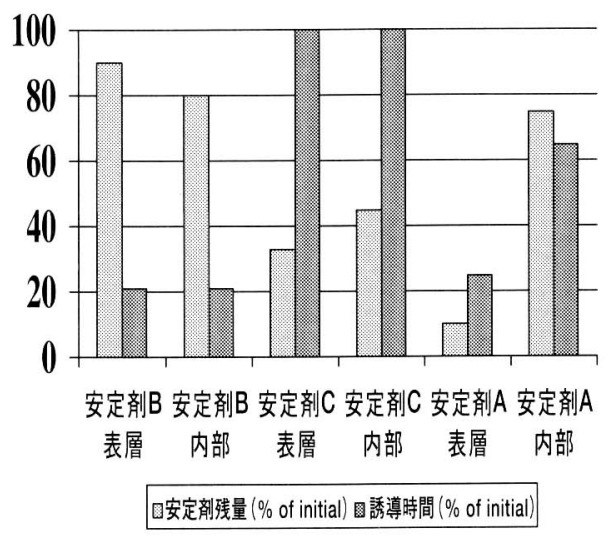

四 1 BR ゴムの安定剤残存量とブラベンダー劣化試験による誘導時間
測する通り加工安定性は，加工安定剤の添加量やその種類 に依存する。しかし，安定剂添加量の口スは，保管時にお ける合成ゴムの加工安定性の変化について信頼できる指標 ではない。したがって，ムーニー粘度のような標準試験結 果と，生ゴムの長期保管後に残された加工安定性の関係の 有無について検討した，今回の検討では，2 種類のSSBR ゴムを用い，一つは市販のS-SBRで，他方は $0.1 \%$ の安定剤Cで安定化されたS-SBRで実施する.

\section{1 生ゴムのオーブン熱劣化試験}

$70{ }^{\circ} \mathrm{C}$ 熱履歴を負荷したS-SBR と負荷しないS-SBRに ついて，ムーニー粘度とブラベンダー熱劣化試験をする。 2 種類のS-SBRは， 6 週間までほほ同様のムーニー粘度 を示すが，安定剤Cで安定化されたS-SBRはより長期の 安定性を示玄(図 2)。次に，市販のS-SBRに熱履歴を負 荷していない試料と $70{ }^{\circ} \mathrm{C} て ゙ 5$ 週間熱履歴を負荷した生ゴ ムについて，110 ㄷ゙のホットシェアリング試験の結果を 示す (図 3 ). 熱履歴を負荷していない市販のS-SBR は, 30 分以上の誘導時間を示し高い安定性をもつ。しかし，5 週間の熱履歴を負荷したS-SBRは，2 試料ともにほほ同 等のムーニ一粘度を有するが, 誘導時間は 7 分と著しく低 い安定性を示す・トルクの上昇は，酸化から生ずる架橋反 応に起因する．安定剂Cで安定化の場合，両方の生ゴムに 架橋反応を示唆するようなトルクの上昇はない.これらの 結果から判断して，ムーニー粘度とホットシェアリング試 験の誘導時間に関連性はないものと考察する.

オーブン熱劣化試験の項目として，ムーニー粘度とブラ ベンダー熱劣化試験による誘導時間について要約する：安 定剂 Cで安定化したS-SBRは，ムーニー粘度の安定性， また生ゴムの加工安定性にも変化を与えない，市販のSSBRの場合，ムーニー粘度に変化を与えないが, 誘導時 間については30分から 7 分となり加工安定性が低下する (図 4).次に生ゴムの安定性について要約する：生ゴムは, ムーニー粘度あるいはゲル化量が上昇するずっと前から，

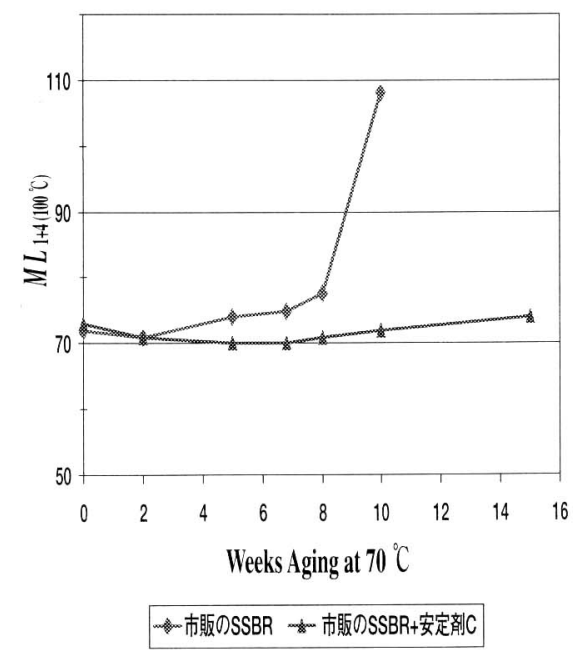

図 $270^{\circ} \mathrm{C}$ オーブン劣化試験後のS-SBRゴムのムーニー粘度 
市販のS-SBRゴム

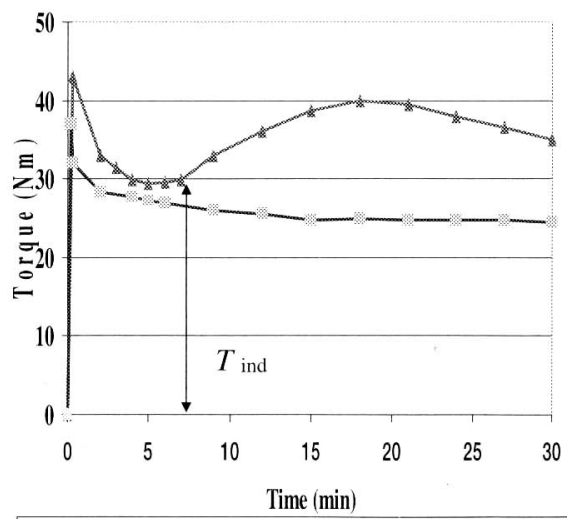

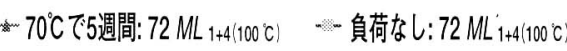

安定剤Cで安定化したS-SBRゴム

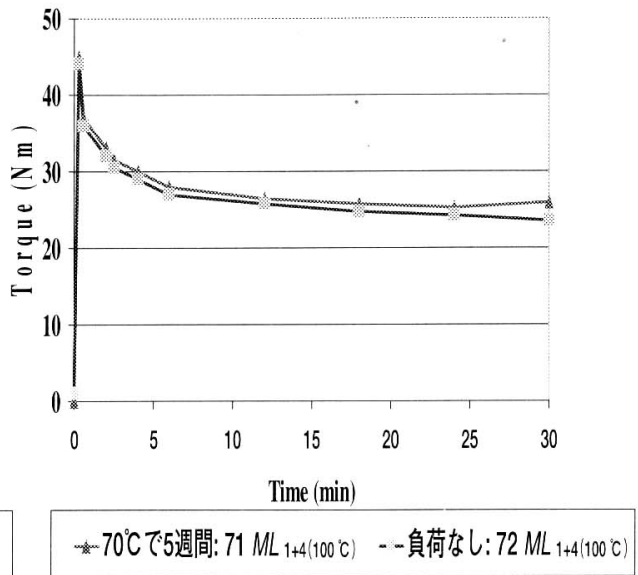

四 3 S-SBR ゴムの $110{ }^{\circ} \mathrm{C}$ ホッシェアリング試験後のトルクの変化

保管時において変化を受ける。この保管時に引き起こされ る変化は, 酸化劣化であり酸化防止剤に依存する.この最 初の 2 つ実例は, 残存した安定剤の濃度やムーニー粘度 が残された加工安定性について信頼できる指標ではないこ とを示した．この観点から，生ゴムの保管時や熱劣化後の ブラベンダー熱劣化試験が示す誘導時間が，ゴムコンパウ ンド時の加工性を結論付けできるかを検証した。

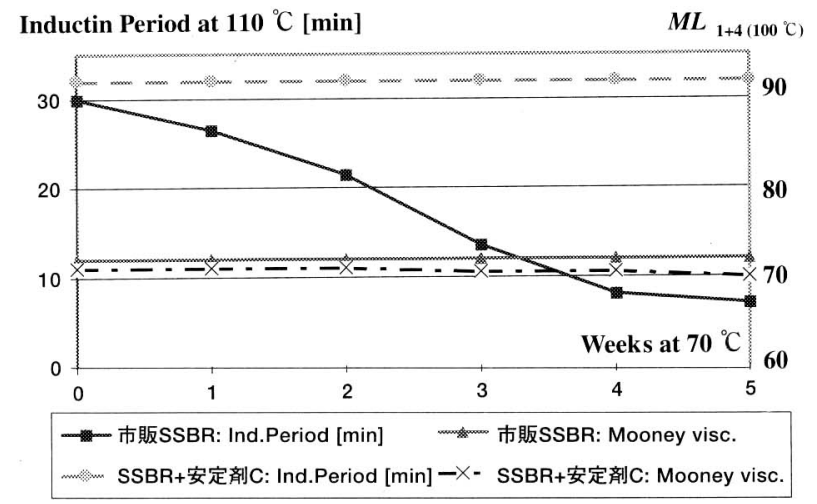

四 $470^{\circ} \mathrm{C}$ オーブン劣化試験後のS-SBR ゴムのムーニー粘度と誘導 時間の関係

市販のS-SBRゴム

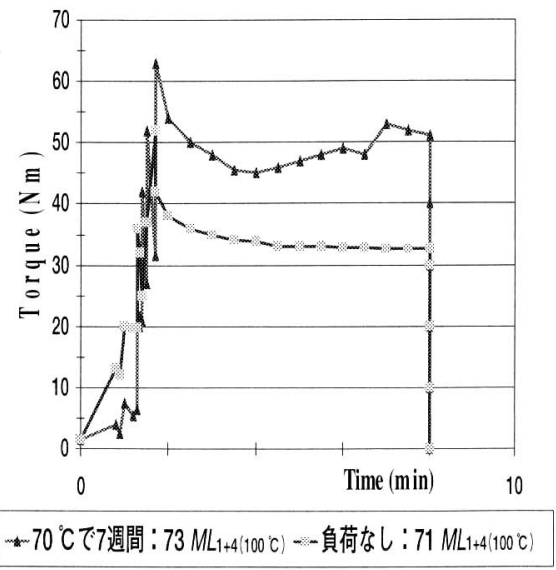

図 5 カーボンブラック人り S-SBRゴムの練り試験

\section{3. カーボンブラック入り S-SBR コンパウンド配合}

熱履歴を負荷したゴムと負荷していない 2 種類の $\mathrm{S}$ SBRを用い，ラボニーダーでカーボンブラックを配合し たゴムコンパウンド試料を調製し検討した。市販のSSBRに熱履歴を負荷しない場合と 7 週間負荷した場合の 練り曲線を示す．明らかに2つの曲線には相違がある。生 ゴムのムーニー粘度は71 と 73 でありほほ同一であるが， 練り曲線の最終トルクから算出した練りエネルギーはかな り異なる (図 5 左). 安定㘊Cで安定化したゴムが使われる 場合，熱履歴の負荷にかかわらず練り曲線は一致する(図 5 右).

これらの練り試験結果をホットシェアリング試験と比較 すると, 調查結果の一致は明らかである：安定剤Cは， 2 つの試験に掞いてのトルクの上昇はなく，すなわち望まし くない酸化による架橋はない. 我々は, 市販のゴム試料で, 練り試験の結果と同様にホットシェアリング試験でも強い トルク上昇を確認した。つまり，ブラベンダー熱劣化試験 とヘンシルミキサーを用いた测定結果は，ゴム保管後の残

\section{安定剤Cで安定化したS-SBRゴム}

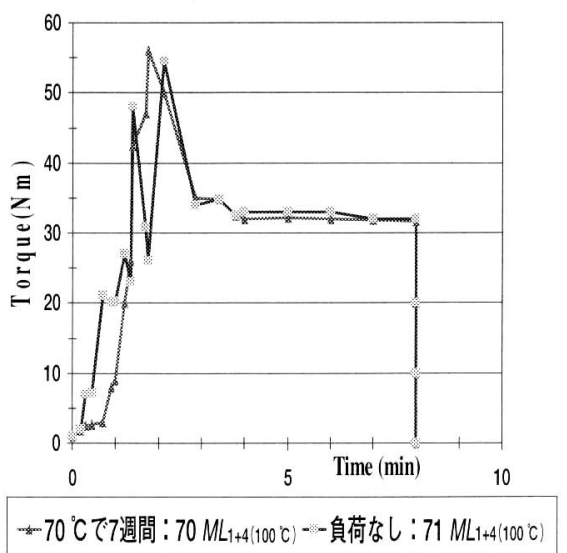


された加工安定性と相関性がある。

\section{4. 最適化された加工安定剤を用いたゴムコンパウンド の加工性改良}

初期の練り段階での最適な安定剂の添加が, 生ゴムの保 管時に劣化を受けたため減少した加工安定性を有するゴム の酸化による架橋を防ぐことができるかどうか検討した. この目的のために, 市販の低シスポリブタジエンを $70{ }^{\circ} \mathrm{C}$ で 3 週間まで熱履歴を負荷する。この期間ではムーニー粘 度は一定であるが $150{ }^{\circ} \mathrm{C} て ゙ ~ 40 \mathrm{rpm}$ の条件下でブラベンダ 一熱劣化試験を実施したところ, 安定剤無添加での誘尊時 間は 3 分であった。しかし, 図6のトルク曲線に示すよう に, $0.2 \%$ の新規加工安定剂 (化学構造は非公表, 以後PSS 1) 添加では 60 分以上の誘導時間を有する。ゴム保管期間 での過酸化物形成に起因する加工性の問題を防ぐシステム であると考察する。安定剂 D は, Ciba ${ }^{\oplus}$ IRGANOX ${ }^{\circledR}$ PS800 (ジドデシル 3,3-チオプロピオナート), 安定剤 $\mathrm{E} は \mathrm{PPD}$ (パラフェニレンジアミン誘導体)である.

\section{5. 練りエ程でのゴムコンパウンドの酸化による架橋の防止}

高い摩擦熱を発する練り工程で熱履歴を負荷していない ゴムを用いたとしても，酸化による架橋の結果として粘度 が増加する。したがって, 望まれていないゴムの架橋を防

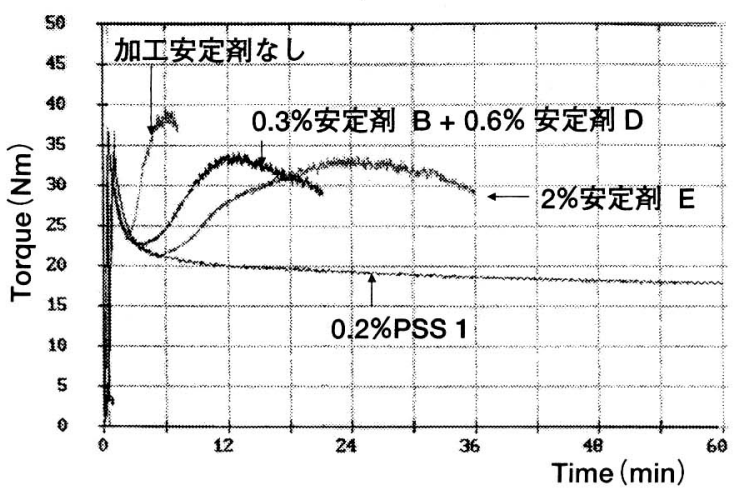

困 6 BRゴムの $150{ }^{\circ} \mathrm{C}$ ホッシェアリング試験後の加工安定剂の効果
止するため, 加工安定片が必要であり PSS 1を開発した.

このPSS 1の効果は，EPDMカーボンブラックマスター バッチ配合においても立証された。100部の EPDMに70 部のカーボンブラック $(\mathrm{N} 550)$ を $180{ }^{\circ} \mathrm{C} て ゙ 45 \mathrm{rpm} の$ 条件下 のブラベンダー熱劣化試験で混合する.新規加工安定剂は, 練り工程の初期段階で添加する. 加工安定剤を添加しない 場合，カーボンブラックを練り配合する間，トルクは鋭く 増加する(図 7 )。1\%のPSS 1 は，30分間の練り時間でさ えトルク上昇を完全に防ぐ.

\section{6. ま と め}

酸化に対し不十分な安定化では，ゴムコンパウンドの加 工時に望まれない酸化による架橋が生ずる結果となる，加 工時の問題を避けるための最初の段階は，合成ゴムの基本 安定剂に効果的な酸化防止剂を使用することである。第二 段階として，ムーニー粘度やゲル化量の測定と同様に，ゴ ムの長期保管後の酸化防止剤の残存量の測定は, 残った加 工安定性についてのみ限定的な意味がある.

合成ゴムの基本安定剤として安定剤 $\mathrm{C}$ は，ゴムの長期保 管期間後であっても高い加工安定性を示すことは前述のよ うに検証した通りであり，加工問題にかかわる保管及び輸 送については避けることはできない。

合成ゴムの長期保管後の結果として加工安定性が低下し たゴムでさえ，練り工程の初期段階で特別な加工安定剤を 添加することによって問題なくコンパウンドが可能であ る.ゴムコンパウンドの加工時において，酸化による架橋 については，ゴム配合組成のコントロールあるいは新しい 加工安定剂システムを使用するプロセスで予期せ好効果を 発揮できる。

なお，本論文の技術的な詳細は，チバ・スペシャルテ イ・ケミカルズ(本社: スイス，バーゼル)，プラスチック 添加剤セグメント，スキルセンター合成ゴム分野室長，ゲ リット・クノブロッフ博士がIRC 2005 YOKOHAMA 28G7-05にて研究発表した「Improved Processing Stabilizer Systems for Rubber Compounding」を参照されたい.

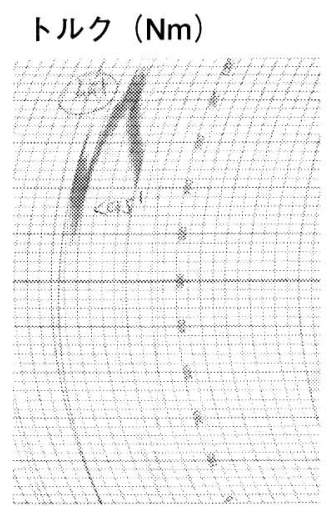

加工安定剤なし

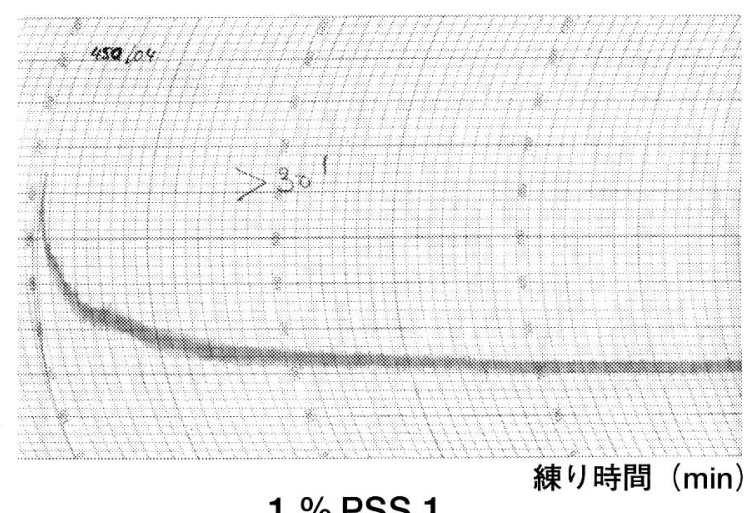

$1 \%$ PSS 1

図 7 カーボンブラック入り $\mathrm{EPDM}$ のミキシング曲線 $\left(180^{\circ} \mathrm{C} / 45 \mathrm{rpm}\right)$ 